\title{
A strategy to address the task of seismic micro-zoning in landslide-prone areas
}

\author{
G. Vessia ${ }^{1}$, M. Parise ${ }^{2}$, and G. Tromba ${ }^{3}$ \\ ${ }^{1}$ University “G. D'Annunzio" of Chieti-Pescara, Chieti Scalo, Italy \\ ${ }^{2}$ National Research Council of Italy, IRPI, Bari, Italy \\ ${ }^{3}$ Civil Engineer, Matera, Italy
}

Correspondence to: G. Vessia (g.vessia@unich.it)

Received: 5 February 2013 - Revised: 4 May 2013 - Accepted: 17 May 2013 - Published: 26 June 2013

\begin{abstract}
As concerns landslide prevention and mitigation policies at the urban scale, the ability of Geographical Information Systems (GIS) to combine multi-layered information with high precision enables technicians and researchers to devote efforts in managing multiple hazards, such as seismically induced instability in urbanized areas. As a matter of fact, many villages in the Italian Apennines, placed near high-energy seismic sources, are characterized by active sliding that are seasonally remobilized by rainfall. GIS tools can be useful whether accurate Digital Elevation Models (DEM) are available and detailed mechanical and hydraulic characterization of superficial deposits over significant portion of the urban territory is undertaken. Moreover, the classic methods for estimating the seismic-induced permanent displacements within natural slopes are drawn from the generalization of Newmark's method. Such method can be applied to planar sliding mechanism that can be considered still valid wherever shallow landslides are generated by an earthquake. The failure mechanism depends on the mechanical properties of the superficial deposits. In this paper, the town of Castelfranci (Campania, southern Italy) has been studied. This small town, hosting two thousand inhabitants, suffers from the seasonal reactivation of landslides in clayey soil deposits due to rainfall. Furthermore, the site is seismically classified by means of the peak ground acceleration (PGA) equal to $0.246 \mathrm{~g}$ with respect to a $475 \mathrm{yr}$ return period. Several studies on the evolution of slopes have been undertaken at Castelfranci and maps have been drawn at the urban scale not taking into any account the seismic hazard. This paper shows possible seismically induced hazard scenarios within the Castelfranci municipal territory aimed at microzonation of level 2 , by estimating the slope permanent
\end{abstract}

displacements comparable to those caused by the strongest historical seismic event that hit this area: the 1980 Irpinia earthquake. To this aim, geotechnical characterization of local soils collected over the last $25 \mathrm{yr}$ by local technicians have been used to predict possible permanent displacements by means of Newmark's sliding block approach. Two simplified relationships relating peak ground acceleration and Arias intensity to permanent displacements have been used and compared. Although similar results are drawn, the two analyses point out the most hazardous sectors of the Castelfranci urban area.

\section{Introduction}

The recent Italian classification of seismic hazard (MPS Working Group, 2004) shows that most of the national territory is included within medium and high seismic hazard zones, with reference return period of $475 \mathrm{yr}$. Planning tools at the municipality level must comply with seismic microzoning maps dealing with co-seismic effects such as local amplification, instability, liquefaction and fault effects, if the case. These activities are currently regulated by means of guidelines provided by the national Department of Civil Protection (DPC Working Group, 2008) that suggest suitable procedures to quantify the co-seismic effects based on the latest updates from the scientific literature. In particular, three micro-zoning levels are considered, at the 1:5000 working scale, with increasing quantitative characterization of the ground response from level 1 to level 3. Nonetheless, each co-seismic effect shows specific critical points that have to be managed by means of scientific tools before being formalized 
within procedures to be used into the professional activity. As seismically-induced landslides are concerned, seismic instability maps are feasible although the following weaknesses have to be considered:

- No physical differences can be outlined between kinetic mechanism under seismic and rainfall triggering conditions;

- In wet seasons, the role exerted by the rainfall regime on instability at the time of the hypothetical earthquake cannot be assessed;

- The most common microzonation maps of seismicallyinduced landslides rely on the Newmark sliding block approach that needs initial stable conditions and translative slope movements to be applied. This issue is not always verified and/or monitored.

This study tries to tackle the microzonation study at level 2 of the active unstable territory at the Castelfranci municipality (Campania, southern Italy), a site with high seismic hazard (maximum expected peak horizontal acceleration $a_{\mathrm{g}}$ is $0.246 \mathrm{~g}$, with return period of $475 \mathrm{yr}$ ) where relevant instability phenomena are in progress. In this study, some updated methods for permanent displacement estimation have been implemented by means of Geographic Information System (GIS) and a Digital Elevation Model (DEM) with $10 \mathrm{~m}$-cell size grid (Tarquini et al., 2007). The landslide map of the Castelfranci territory (Peluso, 1999), officially accepted by the local authorities, and depicting active and dormant landslides in the area at the scale 1:5000 (Fig. 1), has been used as reference map. Finally, an accurate analysis of lithological and geotechnical characteristics of the site has been carried out by critically examining twenty-year field and laboratory investigations: these represent a reliable amount of data for estimating future possible seismically induced landslides.

\section{Geological and geomorphological settings of Castelfranci municipal territory}

The town of Castelfranci (Fig. 1) is located on the eastern (right) side of the Calore River, along a N-S rectilinear stretch of the water course. From the geological standpoint, the area shows outcrops belonging to the Miocene Castelvetere Formation, resting over the carbonate platform deposits of the Alburno-Cervati and Maddalena Mts. Unit (Patacca et al., 1990; Menardi Noguera and Rea, 2000; Patacca and Scandone, 2007). The Castelvetere Formation consists of turbiditic sandstones, in layers from a few centimetres to about $10 \mathrm{~m}$ thick, and chaotic intervals with prevailing clay deposits that include large blocks of variable lithologies (limestones, slates, marls, etc.).

In particular, the Castelfranci area is characterized by two lithological complexes (De Vita et al., 2001): the first is prevailingly clay, with presence of calcareous breccias, and in-

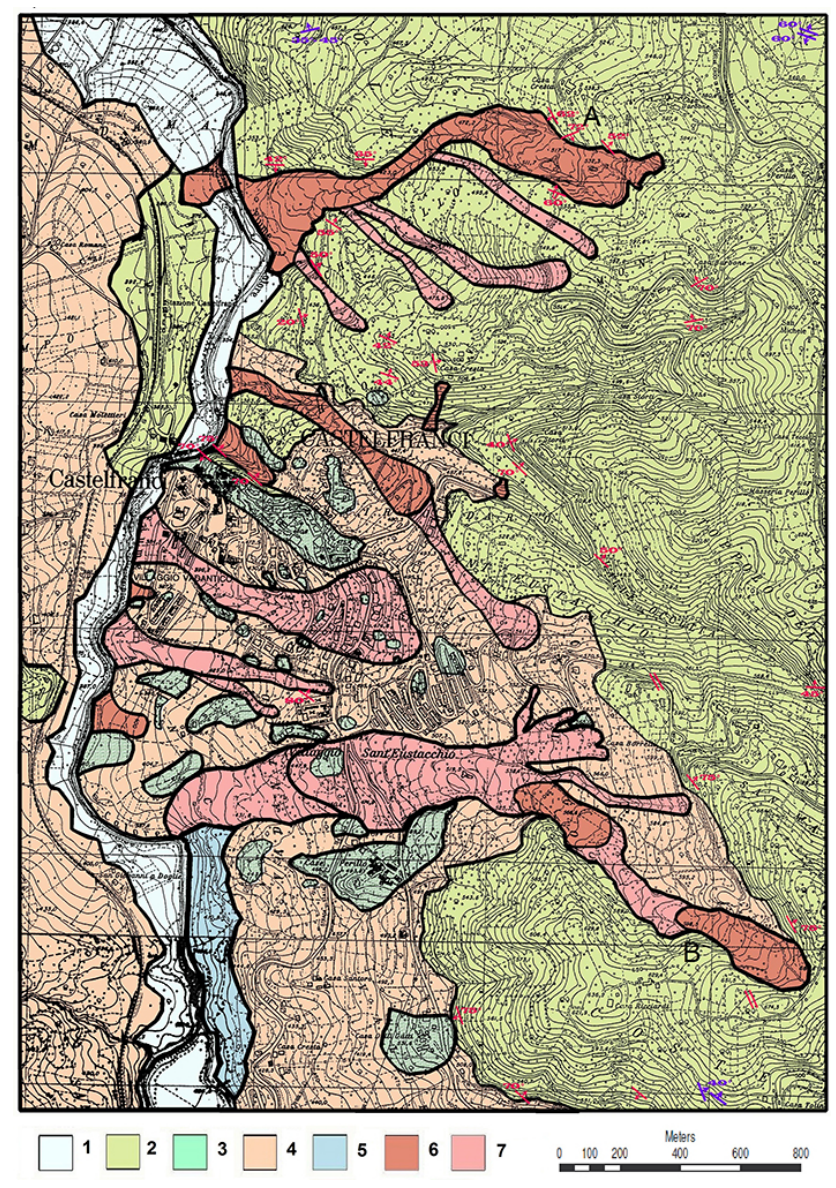

Fig. 1a. Landslide and geological map of Castelfranci municipality (modified after Peluso, 1999). Legend: (1) recent alluvial deposits; (2) sandstone complex; (3) wildflysch olistostromes; (4) clay complex; (5) conglomerates; (6) active landslide; (7) dormant landslide. The two major landslides in the area are indicated (A is the Chianiello landslide, B the Lago landslide).

clusions of sandstones and slates; these materials pass laterally to sands and clay silts. The second complex consists, on the other hand, of a rhythmic turbidite succession of bedded sandstones and conglomerates, with a progressive finingupward sequence leading to massive sandstones. The latter complex crops out along a NW-SE stretch (Fig. 1a), which comprises the upper reaches of the catchments, including the source areas of the main slope movements in the area. The clay complex characterizes the urban area of Castelfranci, and the valley of the Calore River (Fig. 1a).

The geological succession has been strongly affected by tectonic activity, which produced development of several wide folds and deformations, such as those characterizing the sectors north of the town. The overall setting shows therefore a mostly rigid complex (i.e., the sandstones and conglomerates) resting over a more plastic one (clay-calcareous complex). This favors the high predisposition to landslides, especially when combined to peculiar tectonic situations 


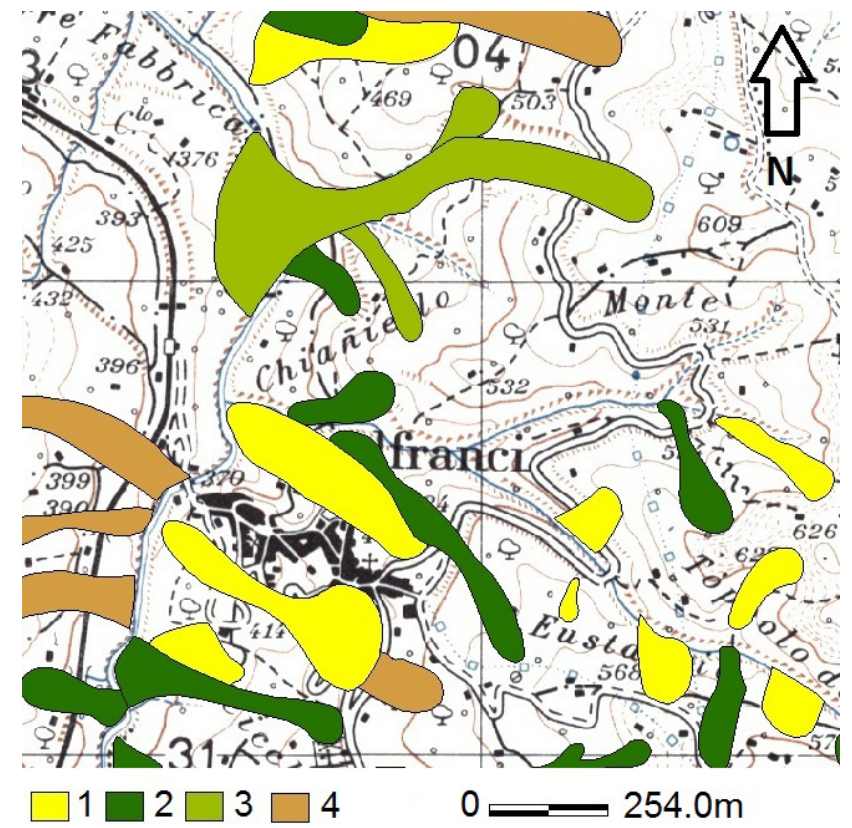

Fig. 1b. IFFI landslide map at Castelfranci. Legend: (1) translative/rotational sliding mechanism; (2) earthflow; (3) mud flow; (4) complex landslide mechanism.

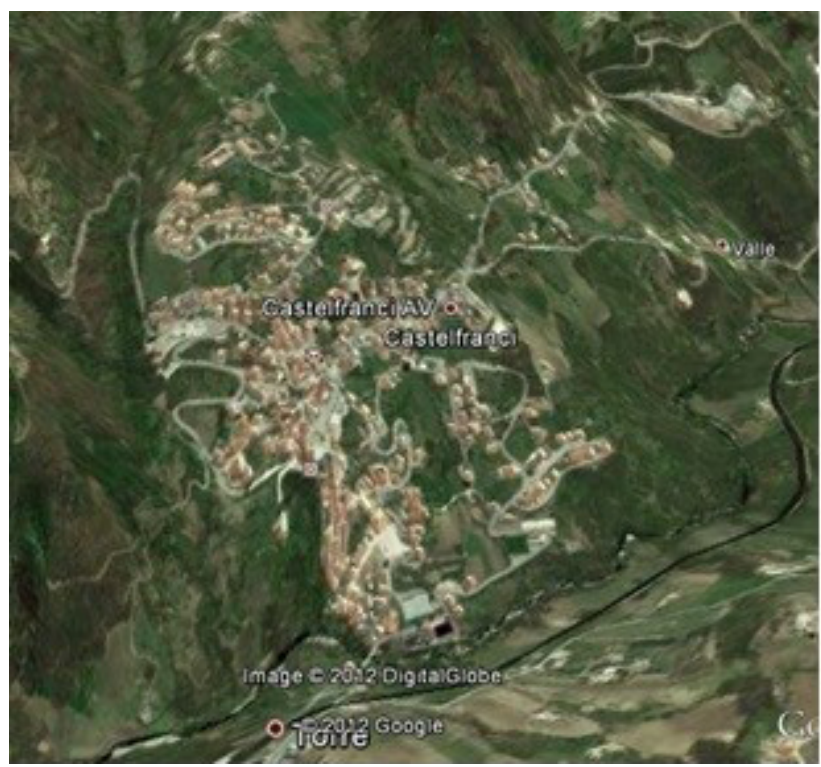

Fig. 1c. Google map 3-D view of Castelfranci (look to the east).

(i.e., the limbs of a fold, slopes in highly tectonized materials, etc.).

As regards geomorphology, the right side of the Calore River is made of low hills, deeply incised by a structurallycontrolled network of valleys (Fig. 1c). Relief is on the order of some hundreds of meters, from the highest reaches of the catchments (about $700 \mathrm{~m}$ a.s.l.) to the Calore River valley floor (350-400 $\mathrm{m}$ a.s.l.). Most of the area is heavily mod- eled by ancient gravity-related phenomena, which remnants can be recognized in the upper catchments as old and steep scarps, mainly related to slope movements belonging to the category of rotational slides. Part of these features may be remobilized, due to several triggering actions, including rainfalls, moderate to strong seismic shocks, and anthropogenic activities (De Vita et al., 2001). In some cases, the landslide deposits move downslope as flows, and reach the valley floor of the Calore River, eventually causing diversions of the water course. On the occasion of the most significant reactivations the landslides may also cause temporary damming of the river.

Two slope movements are the most important in the Castelfranci area, in terms of size and state of activity (sensu WP/WLI, 1993): the Chianiello landslide (A in Fig. 1a), north of the town, and the Lago landslide (B in Fig. 1a), to the south, nearby the cemetery. Both the phenomena start as rotational slides from wide catchments that have been clearly modeled by palaeo-landslides. Due to the prevailing clayey nature of outcropping materials, the slope movements soon evolve into flows. The main landslide bodies (terminology of landslide features according to IAEG Commission on Landslides, 1990) are also fed by further minor contributions from lateral slope movements, and, after a course along preexisting valleys, reach the Calore thalweg, creating prominent landslide feet. Even though the phenomena may be identified as flows in the classical Cruden and Varnes' classification (1996), the observation of well-defined and continuous shear surfaces at the boundaries of the moving material (see Fleming and Johnson, 1989; Parise, 2003; Parise et al., 2003), accompanied by development of long flank ridges, highlights their character of mudslides (Hungr et al., 2001; Hungr, 2003), which represents the type of slope movements most common in large portions of the Southern Apennines of Italy (Pellegrino et al., 2003; Parise et al., 2012). In the study area, the inventory of landslide phenomena produced by the project IFFI (Inventory of Landslide Phenomena in Italy; http://www.pcn.minambiente.it/) (Fig. 1b) highlights the sliding character of the Lago landslide and of other unstable phenomena around Castelfranci where the clay complex of the Castelvetere formation crops out. The Chianiello landslide, on the other hand, is classified in this map as a mudflow within the turbiditic sandstones.

Historical data about movements of the landslides at Castelfranci are not very abundant, with a few reactivations documented (see Table 1). With the exception of the reactivations related to the 1980 earthquake, all the other dates refer to rainfall trigger. Notwithstanding the low amount of available data, on the basis of direct testimonies from the inhabitants it can be stated that the main movements appear to show almost a continuous activity, even though not involving the whole phenomena but rather being localized in limited sectors of the unstable areas. 
Table 1. Known dates of (re)activation for the Chianiello and Lago landslides.

\begin{tabular}{|c|c|}
\hline Date & Description \\
\hline April 1958 & $\begin{array}{l}\text { Damage to } 4 \text { houses in the source area } \\
\text { of the Chianiello landslide }\end{array}$ \\
\hline 2 May 1976 & $\begin{array}{l}\text { Catastrophic reactivation of the Chian- } \\
\text { iello landslide, after a winter with high } \\
\text { rainfall values. Partial damming of the } \\
\text { Calore River }\end{array}$ \\
\hline 23 November 1980 & $\begin{array}{l}\text { Earthquake-induced reactivations of } \\
\text { both the Chianiello and Lago land- } \\
\text { slides, following the Irpinia earthquake } \\
\left(M_{\mathrm{e}}=6.9\right) \text {. }\end{array}$ \\
\hline 10-12 January 1996 & $\begin{array}{l}\text { Partial re-activation within a sector of } \\
\text { the catchment of the Lago landslide. }\end{array}$ \\
\hline 1996-1997 & $\begin{array}{l}\text { Retrogressive evolution of the source } \\
\text { area of the Chianiello landslide, and se- } \\
\text { vere erosion at the foot, as a conse- } \\
\text { quence of the intense and prolonged } \\
\text { rainfall of the winter season. }\end{array}$ \\
\hline 13 February 1999 & $\begin{array}{l}\text { Partial re-activation within a sector of } \\
\text { the catchment of the Lago landslide. }\end{array}$ \\
\hline
\end{tabular}

\section{Geotechnical characters of outcropping deposits at Castelfranci site}

As mentioned before, the Castelfranci site is characterized by outcrop of deposits belonging to the Castelvetere formation, which can be subdivided into the two complexes delineated above, a clay and a sandstone one, respectively. The Chianiello landslide (A in Fig. 1a) develops into the sandstone unit, whilst the Lago landslide (B in Fig. 1a) involves both the lithotypes, starting from the sandstone unit, and then developing in the clay unit. However, because of the chaotic setting of outcropping materials, and the structurally complex nature of the rock units, the two complexes do not show appreciable differences in the cohesion and shear strength properties. Thus, results from laboratory tests will be plotted and discussed together, hereafter.

Mechanical properties of the soil units have been measured and determined in the time span from 1988 to 2010, and derive from a number of surveys and tests (borehole with continuous coring, standard penetrometer, down hole, piezometer readings, inclinometer readings, seismic refraction, etc.), carried out at maximum depth of $35 \mathrm{~m}$, and appointed by the Castelfranci municipality to local practitioners. Such investigations were performed and interpreted by different technicians, both in situ and in laboratory, and were not aimed at delineating the soil response over the whole territory to triggering actions such as rainfall and earthquake. Nevertheless, results from these tests represent a precious

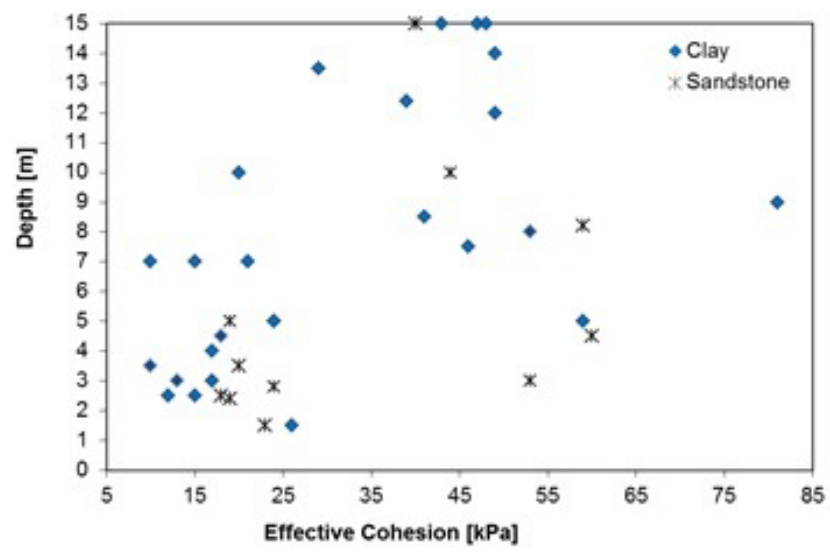

Fig. 2. Effective cohesion measured in the municipal territory of Castelfranci.

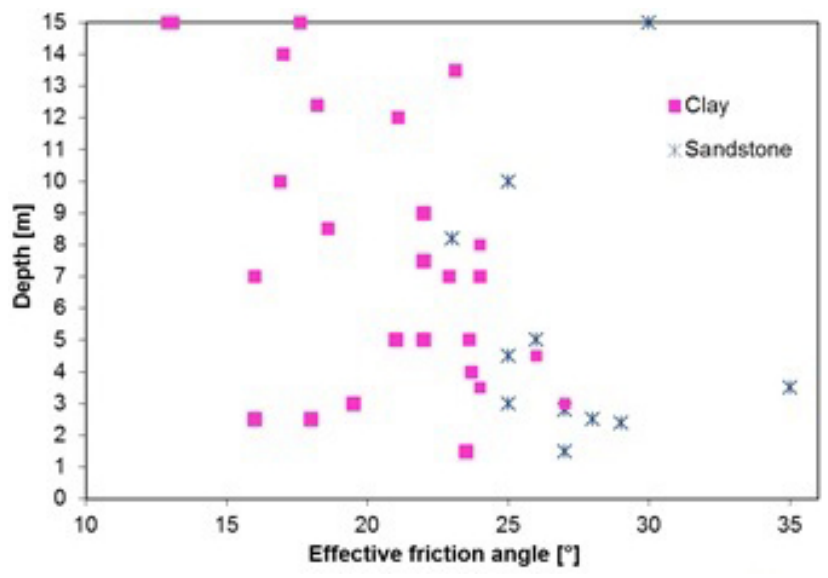

Fig. 3. Effective friction angles measured in the municipal territory of Castelfranci.

source of information, even though non homogeneous, at Castelfranci. For this reason, a critical analysis of the test results was performed, and the most reliable mechanical data in terms of effective cohesion and friction angles were extracted to characterize both the intact and mobilized rock masses. Results in terms of 25 values of effective cohesion and shear strength derived from simple shear tests in the clay complex, and 11 in the sandstones, down to $15 \mathrm{~m}$ depth, are summarized and shown in Table 2. Many of the sampled soil units have been involved into landslide phenomena during the last $25 \mathrm{yr}$ although rarely sliding surfaces were detected. Moreover, two measures of residual shear strength and cohesion in sandstone complex have been performed at $2.5 \mathrm{~m}$ depth. Based upon measurement campaigns, Figs. 2 and 3 show the trend of effective cohesion and shear strength with depth. As concerns effective cohesion (Fig. 2), the values concentrate between $7-25 \mathrm{kPa}$ for the clay unit and between $16-25 \mathrm{kPa}$ for the sandstone unit at depth lower than $5 \mathrm{~m}$; in the range of depth 5-10 m, only two values (44 and $59 \mathrm{kPa}$ ) for sand- 
Table 2. Geotechnical properties of the lithotypes cropping out at Castelfranci.

\begin{tabular}{lcccc}
\hline Lithology & $c^{\prime}(\mathrm{kPa})$ & $\varphi^{\prime}\left(^{\circ}\right)$ & $\gamma\left(\mathrm{kN} \mathrm{m}^{-3}\right)$ & Depth of slip surface $(\mathrm{m})$ \\
\hline Sandstone complex & 20 & 28 & 21 & 5 \\
Clay complex & 20 & 23 & 19 & 7 \\
Active landslides & 5 & 14 & 17 & $5-7$ \\
Dormant landslide in clay & 5 & 14 & 17 & 5 \\
Dormant landslides in sandstone & 15 & 25 & 18 & 7 \\
Olistostromes & 100 & 40 & 26 & - \\
\hline
\end{tabular}

stones, and 7 values (between 7 and $54 \mathrm{kPa}$ ) for the clay complex are available. Such large ranges of values can be due to the presence of both the sliding surface and the groundwater (between 5-10 $\mathrm{m}$ and 5-7 m, respectively). At depth greater than $10 \mathrm{~m}$, the effective cohesion in clay shows a reduced variation from $43 \mathrm{kPa}$ to $53 \mathrm{kPa}$, whereas one value of $40 \mathrm{kPa}$ has been measured in sandstone. As the shear strength is concerned, within the first $5 \mathrm{~m}$ of depth and down to $14 \mathrm{~m}$, the effective friction angle is in the range $16-27^{\circ}$ for the clay complex. The sandstone effective friction angles, on the contrary, vary within $25-29^{\circ}$ until $5 \mathrm{~m}$ of depth (Fig. 3) and reduce to $23-25^{\circ}$ from 8 to $10 \mathrm{~m}$ of depth; at depth of $15 \mathrm{~m}$ the value of $30^{\circ}$ is reached. Provided that the authors cannot evaluate the quality of this dataset due to the temporal gap of the performed tests ( $25 \mathrm{yr}$ ) and the number of different laboratories involved, the variation along depth is only considered in selecting the mechanical and physical values for intact clay and sandstone units. In the study, mean values over the first 5-7 $\mathrm{m}$ have been considered for those portions of the sandstone and clay complex not involved in sliding phenomena. In these two cases, a coefficient of variation (CV) of $13 \%$ for both effective cohesions and friction angles has been calculated. These CV values are relative to few measures performed on 8 sandstone samples and 15 clay samples. With respect to active landslides, residual values from the two simple shear tests on sandstone and clay complexes are used. Table 2 summarizes the mechanical properties considered for the different lithotypes. For dormant landslides, evidenced in Fig. 1a, values of residuals cohesion and friction angles are used for the clay complex, whereas the minimum effective values corresponding to the depth of the sliding surface are taken into account for sandstone complex. This assumption derives from the fact that slip surfaces have been detected only in the clay complex. Moreover, in the sandstone complex a few values of effective cohesion and friction angles cannot be used for deriving mechanical properties between 5 and $10 \mathrm{~m}$ of depth. Finally, no trends with depth can be derived from the present dataset but clusterized values for clay complex. The authors believe that the "spatial statistical" properties established for this dataset collected over a large time span, relating to chaotic formations involved into sliding movements and variable groundwater levels, cannot be significant.

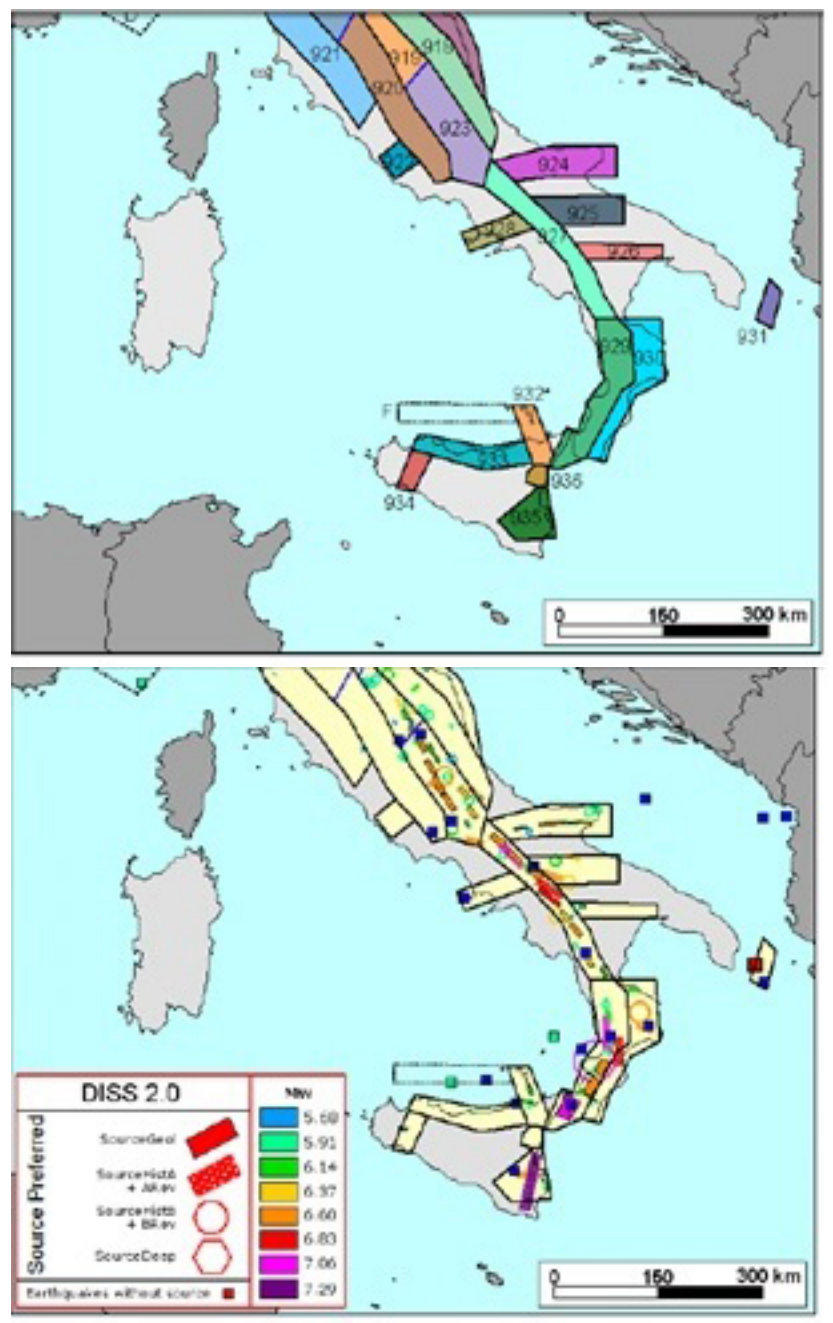

Fig. 4. Seismogenic map of the Southern Italy named ZS9 (OPCM 20.03.2003 n. 3274).

The fifth column in Table 2 shows the slip surface depths detected by a few inclinometer readings within the Castelvetere formation ( 2 readings within the clay complex). As concerns alluvial deposits and conglomerates, due to their low slopes, limited extention and stable character of their mechanical properties are not investigated. Thus, they are not considered within the GIS hazard study. All the ground- 
Table 3. Historical seismicity affecting Castelfranci (after DBMI11, by Locati et al., 2011).

\begin{tabular}{ccclcc}
\hline Intensity at the site & Year/Month/Day & Local time & Epicentral Area & Epicentral Intensity & Mw \\
\hline 8 & $1732-11-29$ & $07: 40$ & Irpinia & $10-11$ & 6.64 \\
7 & $1805-07-26$ & $21: 00$ & Molise & 10 & 6.62 \\
2 & $1887-12-03$ & $03: 45$ & Northern Calabria & 8 & 5.49 \\
7 & $1910-06-07$ & $02: 04$ & Irpinia-Basilicata & $8-9$ & 5.73 \\
7 & $1980-11-23$ & $18: 34: 52$ & Irpinia-Basilicata & 10 & 6.89 \\
$3-4$ & $1982-03-21$ & $09: 44: 02$ & Maratea & $7-8$ & 5.36 \\
$4-5$ & $1982-08-15$ & $15: 09: 54$ & Sele Valley & 6 & 4.68 \\
- & $1984-05-07$ & $17: 49: 42$ & Abruzzo Apennine & 8 & 5.89 \\
$6-7$ & $1990-05-05$ & $07: 21: 17$ & Potenza area & 7 & 5.80 \\
- & $1991-05-26$ & $12: 25: 59$ & Potenza area & 7 & 5.11 \\
$4-5$ & $1996-04-03$ & $13: 04: 35$ & Irpinia & 6 & 4.93 \\
- & $2002-04-18$ & $20: 56: 49$ & Diano Valley & 5 & 4.38 \\
$3-4$ & $2002-11-01$ & $15: 09: 02$ & Daunia Subappenine & & 5.72 \\
- & $2003-06-01$ & $15: 45: 18$ & Molise & 5 & 4.50 \\
- & $2003-12-30$ & $05: 31: 38$ & Frentani Mountains & $5-6$ & 4.57 \\
- & $2004-02-23$ & $19: 48: 45$ & Irpinia & $4-5$ & 4.22 \\
- & $2005-05-21$ & $19: 55: 19$ & Irpinia & $5-6$ & 4.40 \\
- & $2006-05-29$ & $02: 20: 06$ & Gargano Promontory & $5-6$ & 4.63 \\
\hline
\end{tabular}

water table depth values have been collected over the last $25 \mathrm{yr}$ by means of monitoring activities carried out by local practitioners. Twenty piezometric campaigns within the urban area of Castelfranci have been carried out by means of Casagrande piezometers. The investigated area involves the intact clay complex as well as active and dormant landslides. The eight most recent piezometric readings, covering the time span 2005-2010, show the groundwater level at 3$5 \mathrm{~m}$ of depth in the sandstone complex and at 5-8 $\mathrm{m}$ of depth in the clay complex. These few data cannot allow to present a map of piezometric levels but are indicative of slip surfaces at the water table depth according to the observations discussed above on the variation of mechanical properties along depth, plotted in Figs. 2 and 3.

\section{Seismic features of Castelfranci site}

Castelfranci is located in the southern sector of the Apennine chain, in an area affected by the strong seismicity of the seismogenic zone 927, according to the latest Italian Seismogenic zonation ZS9 (MPS Working Group, 2004), where the 1980 Irpinia earthquake was generated with a 6.9 Moment Magnitude (http://itaca.mi.ingv.it/ItacaNet/index.html. According to the Database of the seismogenic source DISS 2.0 (Valensise and Pantosti, 2001; see Fig. 4), zone 927 is placed in the axial Appenine chain sector characterized by extensional tectonics with maximum expected seismic events of 6.83 degree of the Moment Magnitude $M_{\mathrm{w}}$.

According to the Italian Macroseismic database DBMI11 (Locati et al., 2011; http://emidius.mi.ingv.it/DBMI11/), Table 3 reports the most significant events that struck the area. The strongest seismic event was the Irpinia earthquake, that occurred on 23 November 1980, at 18:34:52, with $M_{\mathrm{w}}$ equal to 6.9 and epicentral distance about $29 \mathrm{~km}$ from Castelfranci. This seismic event (Westaway and Jackson, 1987; Boschi et al., 2000), besides being among the strongest shocks registered in Italy in the last decades, and with the most severe consequences in terms of casualties and damage, had remarkable effects on the environment, triggering several large landslides in the Sele Valley and nearby areas, including the Calitri, Senerchia and Buoninventre slope movements (Cotecchia and Del Prete, 1984; Parise and Wasowski, 1999; Calò et al., 2012).

At the present, the technical building code enacted by the Infrastructure Ministerial Decree on 14 January 2008 (Infrastructure Ministry, 2008), attributed a reference acceleration on stiff ground $a_{\mathrm{g}}$ equal to $0.246 \mathrm{~g}$ for a return period of $475 \mathrm{yr}$. This means that, whenever the design of a new structure is performed, the estimate of permanent slope displacements must be provided. Moreover, seismic micro-zoning studies shall be undertaken for urban planning purposes. Thus, according to the recently published guidelines for microzoning studies (DPC Working Group, 2008), microzonation maps are needed at Castelfranci aimed at urban planning and managing the built-up environment where there is the possibility of occurrence of seismically-induced instabilities. These microzonation maps have also to provide information about permanent displacements caused by the maximum expected seismic events for a return period of $475 \mathrm{yr}$. To this end, hereafter, the Irpinia earthquake has been considered as the reference seismic shock for calculating the highest seismic action in terms of peak ground acceleration (PGA) and Arias intensity $\left(I_{\mathrm{A}}\right)$ for drawing the permanent displacement maps within the study area. Although this earthquake is the 
Table 4. Maximum values of PGA and $I_{\mathrm{A}}$ measured at the seismic stations that recorded the Irpinia earthquake on 23 November 1980 at 18:34:53 local time.

\begin{tabular}{lccccc}
\hline $\begin{array}{l}\text { Seismic station } \\
\text { name }\end{array}$ & $\begin{array}{c}\text { Seismic station } \\
\text { code }\end{array}$ & $\begin{array}{c}\text { Seismic soil category } \\
\text { at the station }\end{array}$ & $\begin{array}{c}R_{\text {epi }} \\
{[\mathrm{km}]}\end{array}$ & $\begin{array}{c}\text { Maximum peak ground } \\
\text { acceleration PGA [cm s }\end{array}$ & $\begin{array}{c}\text { Maximum Arias Intensity } \\
I_{\mathrm{A}}\left[\mathrm{cm} \mathrm{s}^{-1}\right]\end{array}$ \\
\hline Torre del Greco & TDG & A & 78.27 & 58.75 & 9.80 \\
Tricarico & TRR & B & 73.32 & 45.44 & 4.59 \\
Vieste & VSS & B & 143.34 & 33.74 & 2.42 \\
Auletta & ALT & A & 23.78 & 56.40 & 7.48 \\
Arienzo & ARN & E & 76.75 & 33.94 & 2.07 \\
Bagnoli Irpino & BGI & B & 21.80 & 183.22 & 44.46 \\
Benevento & BNV & B & 58.54 & 44.67 & 6.35 \\
Brienza & BRN & B & 42.21 & 213.53 & 52.54 \\
Bisaccia & BSC & A & 28.30 & 94.60 & 28.70 \\
Bovino & BVN & B & 54.33 & 47.15 & 5.86 \\
Calitri & CLT & B & 18.86 & 171.77 & 136.44 \\
Garigliano 2 & GRG2 & C & 135.96 & 38.40 & 4.35 \\
Gioia Sannitica & GSN & C & 94.27 & 26.53 & 1.00 \\
Lauria Galdo & LRG & B & 95.74 & 15.43 & 0.36 \\
Mercato San Severino & MRT & B & 46.23 & 138.13 & 52.81 \\
Roccamonfina & RCC & C & 126.22 & 31.08 & 2.76 \\
Rionero In Vulture & RNR & B & 35.58 & 97.26 & 62.06 \\
S. Giorgio La Molara & SGR & A & 65.30 & 16.45 & 0.44 \\
S. Severo & SSV & B & 102.32 & 21.50 & 1.03 \\
Sturno & B & 33.26 & 309.72 & 148.15 \\
\hline
\end{tabular}

highest recorded in the area, as pointed out in Table 4, only one PGA value at the Sturno seismic station is greater than $0.246 \mathrm{~g}$. Furthermore, seismic stations are seldom placed on stiff ground, that is soil type A (only 4 out of the 21 stations), thus the measured PGA values should be accounted for the amplification effects due to B, C and E soil types. As recent studies on 2009 L'Aquila earthquake have demonstrated (among the others Bergamaschi et al., 2011; Di Giulio et al., 2011; Rainone et al., 2013) the seismic responses in both the near and far field conditions are characterized by local amplifications, responsible for surficial acceleration magnitude about 5 times that of input, and for differential damage up to 3 degree in the Mercalli-Cancani-Sieberg seismic intensity scale. In this study, a simplified approach to estimation of the PGA at Castelfranci has been applied by interpolating the PGA values recorded at the seismic stations. In this way, the urban territory of Castelfranci is not affected by a single value of PGA equal to $0.246 \mathrm{~g}$ (according to the $2008 \mathrm{In}$ frastructure Ministerial Decree) but rather by a more realistic range between 0.19-0.196 g.

The PGA estimation has been addressed by means of the following steps:

1. First, the recordings of the 20 seismic stations located in Basilicata, Apulia and Campania that recorded the 1980 Irpinia earthquake have been collected from the Itaca database (http://itaca.mi.ingv.it/ItacaNet/index.html);
2. At each seismic station, the main characters of the recordings during the 1980 Irpinia earthquake have been summarized in terms of PGA and $I_{\mathrm{A}}$. The maximum values from the three components of the recorded waveforms are listed in Table 4 summarized from the Itaca Database;

3. Then, locations of the seismic stations and the Castelfranci site, together with the main features of the reference earthquake, have been introduced within ArcGIS10 for Desktop (Esri 2010);

4. Finally, by means of the natural neighbor spatial analysis technique (Sibson, 1981) implemented in ArcGIS10 (Esri 2010), the PGA and $I_{\mathrm{A}}$ maps have been drawn (Fig. 5a and b).

This procedure allows to overlap the raster maps of the dynamic action parameters with the resistance soil properties and the DEM information for building maps of permanent displacements. In this study the DEM was provided by the INGV site (http://tinitaly.pi.ingv.it/). TINITALY/01 is the new digital elevation model of the whole Italian territory (Tarquini et al., 2007), available upon request as a $10 \mathrm{~m}$-cell size grid (UTM zone 32, datum WGS 84). 

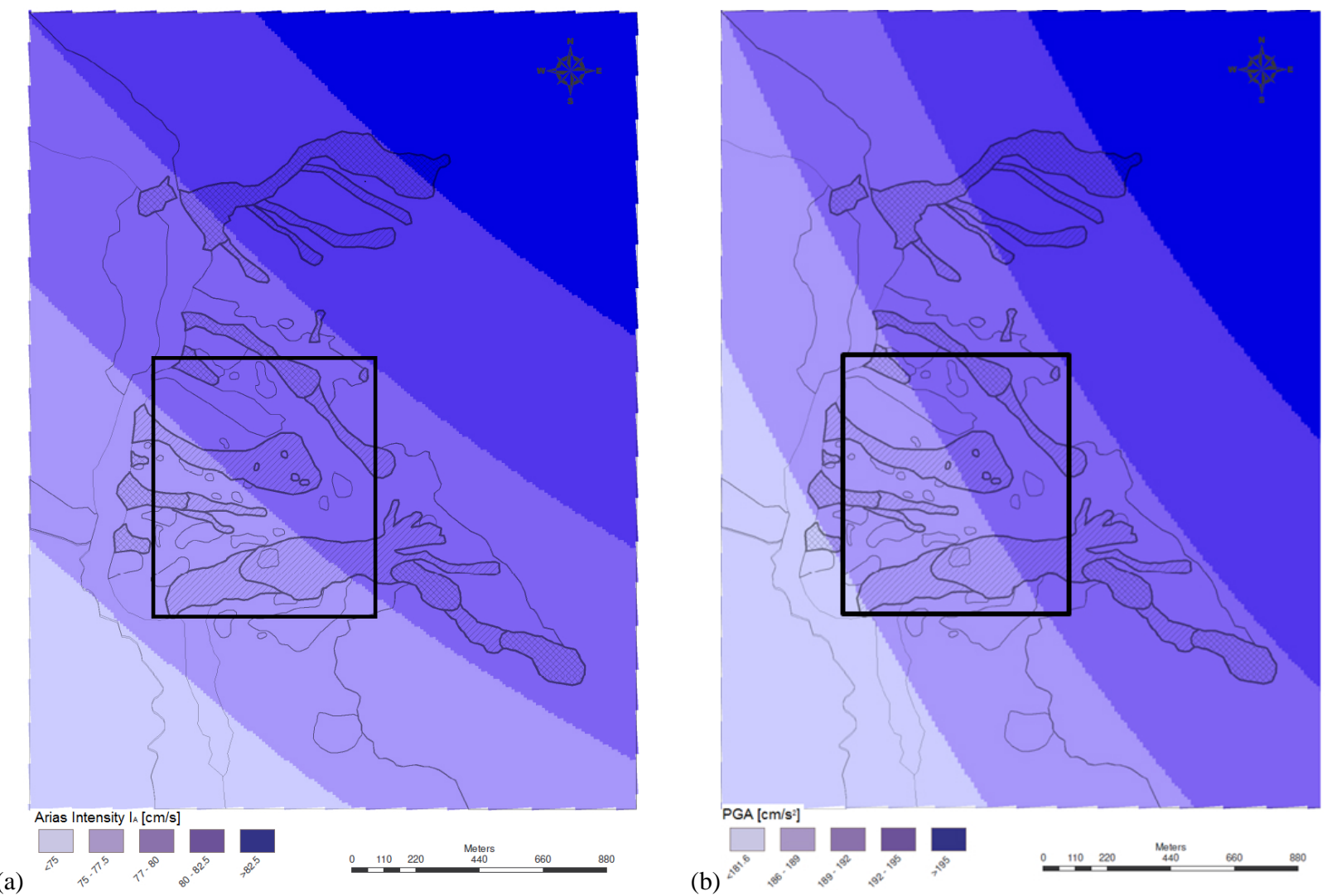

Fig. 5. Interpolated maps of the main features of the 23 November 1980 Irpinia earthquake, derived from the waveforms registered at the twenty seismic stations listed in Table 4: (a) $I_{\mathrm{A}}$ and (b) PGA values. The dark rectangle approximately indicates the urban area.

\section{GIS-based assessment of permanent displacements at Castelfranci}

Assessment of the permanent displacements induced by seismic action within unstable areas can be accomplished by means of three different approaches: (1) the pseudostatic approach, by means of the use of the Pseudostatic Safety Factor calculated as the ratio between the dynamic shear resistance of the slope and the pseudo-dynamic action; (2) permanent displacement estimation, according to the Newmark "sliding block model" (Newmark, 1965); (3) advanced numerical simulations, that can be carried out whenever single slopes characterized by ad hoc investigation campaigns are monitored.

In this paper, focused on the landslide susceptibility of the Castelfranci area for planning purpose, the first two methods above mentioned have been taken into account.

Newmark (1965) extended the pseudostatic analyses and introduced the criterion of displacement rather than stress equilibrium. These results in stability calculations that are dependent on the time when dynamic stress amplitude exceeds the strength and on the amplitude and frequency of the acceleration cycles. Newmark's model has been generalized by various authors in the form of empirical laws (among oth- ers, Ambraseys and Menu, 1988; Jibson, 2007) that calculate the permanent displacements based on strong ground motion parameters, such as Peak Ground Acceleration (PGA), Peak Ground Velocity (PGV), Arias Intensity $I_{\mathrm{A}}$, etc. The landslide susceptibility to failure is generally expressed by the critical horizontal acceleration $k_{\mathrm{c}}$, that accounts for slope geometry, geotechnical properties of soils and hydro-geologic conditions. It is the minimum amount of horizontal acceleration that can bring the slope to the limit equilibrium, that means the Safety Factor (FS) is FS $=1$,. The empirical relationships conform to the general Eq. (1):

$$
\begin{aligned}
& k_{c}(g)=\frac{(\mathrm{FS}-1) \cdot \tan (\alpha)}{1+\tan (\alpha) \cdot \tan \left(\varphi^{\prime}\right)} g \\
& \mathrm{FS}=\frac{c^{\prime}+d\left[\gamma_{\mathrm{sat}}-m \gamma_{\mathrm{w}}\right] \cos ^{2}(\alpha) \tan \left(\varphi^{\prime}\right)}{\gamma_{\mathrm{sat}} \cdot d \cdot \sin (\alpha) \cos (\alpha)}
\end{aligned}
$$

where $c^{\prime}$ and $\varphi^{\prime}$ are, respectively, the effective cohesion and the angle of internal friction of soil according to the MohrCoulomb failure criterion; $\alpha$ is the soil slope, $d$ is the failure surface depth and $m$ is the ratio between the water level and the slip surface depth. The general rule for assessing the permanent displacement can be written as follows:

$\operatorname{Disp}=A \cdot g(s)+B \cdot h(k)+C \pm \sigma$ 

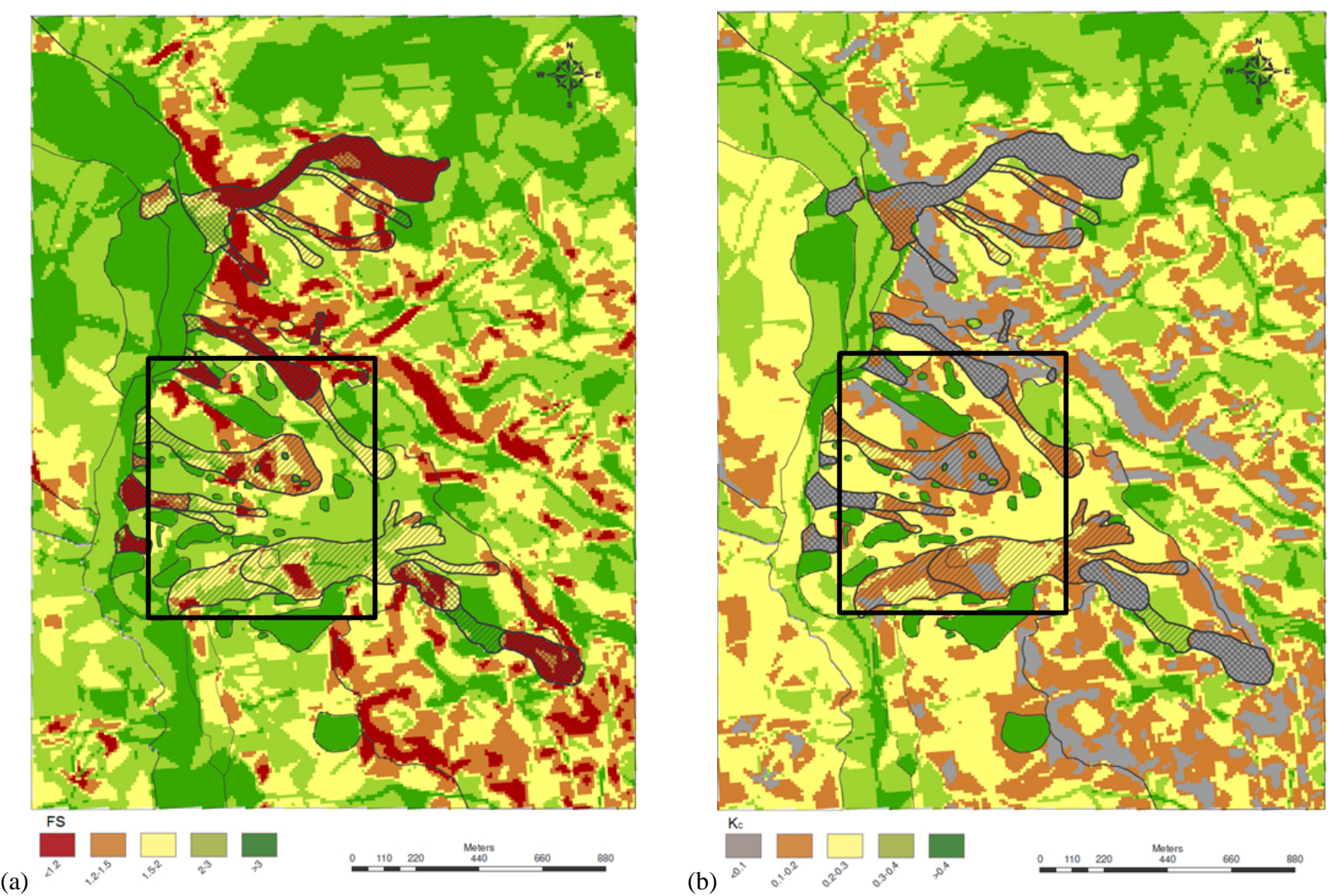

Fig. 6. (a) Safety factor map (FS) and (b) seismic critical coefficient $\left(k_{\mathrm{c}}\right)$ map calculated for the ground water table level at half depth of the slip surface. The dark rectangle approximately indicates the urban area.

where $A, B$ and $C$ are coefficients of the regression analysis, $g(s)$ is the dynamic action, $h(k)$ is the landslide susceptibility to failure and $\sigma$ is the standard deviation of the model. In this paper, two empirical rules have been used to evaluate permanent displacement:

- Jibson (2007):

$$
\begin{aligned}
& \log D(\mathrm{~cm})=0.561 \log \text { (Arias Intensity) } \\
& -3.833 \cdot \log (K)-1.474 \pm 0.616
\end{aligned}
$$

- Ambraseys and Menu (1988)

modified by Jibson (2007):

$$
\begin{aligned}
& \log D(\mathrm{~cm})=-2.710+\log \left[(1-K)^{2.335} \cdot K^{-1.478}\right] \\
& +0.424 M \pm 0.454
\end{aligned}
$$

where $K$, in both the previous equations, is the critical seismic coefficient expressed as:

$K=\frac{k_{\mathrm{c}}(g)}{P G A(g)}$

and $M$ is the magnitude.
Equation (4) introduces the seismic action by means of the Arias intensity, according to Jibson et al. $(1998,2000)$. They expand the initial work of Jibson (1993), showing the utility to use the functional form of Eq. (3) for correlating Newmark displacement with Arias intensity and critical acceleration. Arias intensity (1970) is more significant than the peak acceleration to characterize the energy content of an earthquake record because it accounts for all the acceleration time series and, implicitly, for duration. Jibson (2007) derived the empirical relationship in Eq. (4) by regressing the 875 Newmark displacements extracted from worldwide seismic record archives with magnitude ranging between 6.0 and 7.6. This equation shows a correlation coefficient $R^{2}$ equal to $75 \%$, where $I_{\mathrm{A}}$ is expressed in $\mathrm{m} \mathrm{s}^{-1}$ and $D$ is expressed in $\mathrm{cm}$.

On the other hand, Eq. (5) uses the peak ground acceleration PGA (that overestimates the potential hazard of a strong motion record) associated with the earthquake magnitude as the input motion parameters. This expression is revised by Jibson (2007) and represents the Ambraseys and Menu (1988) equation valid for surface wave magnitude $M_{\mathrm{S}}$ values varying between 5.3 and 7.6.

The two relationships shown in the Eqs. (4) and (5) will be used in the following section. They rely on different parame- 

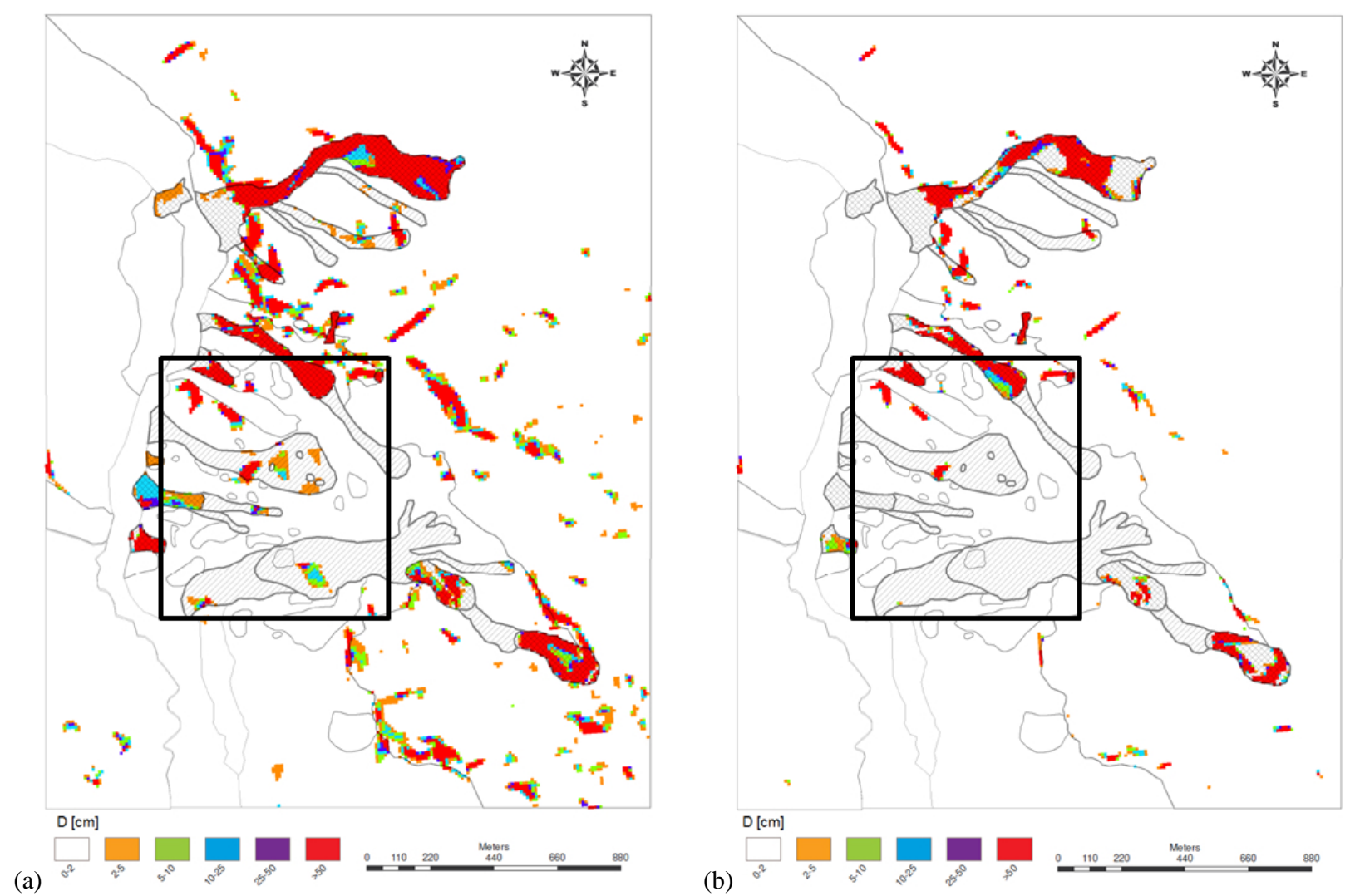

Fig. 7. Permanent displacements calculated by means of the equations by (a) Ambraseys and Menu modified by Jibson (2007), and by (b) Jibson (2007). The dark rectangle approximately indicates the urban area.

ters used to describe the seismic event that are easy to be collected from official websites and, at the same time, describe the earthquake properties. PGA, in particular, focuses on the maximum acceleration as representative of the whole signal. On the other hand, the Arias intensity takes into account the strong motion energy content that can be responsible for the disruptive deformation of the most affected surficial soil units where dormant or active instability takes place.

The differences among permanent displacements predicted for the case study will be discussed in the following.

\section{Discussion on results at Castelfranci}

The study at Castelfranci is here presented in terms of scenarios for seismically induced instability due to the 1980 Irpinia earthquake $\left(M_{\mathrm{w}}=6.9\right.$, epicentral distance $D_{\mathrm{e}} \cong 30 \mathrm{~km}$ from Castelfranci). The maps relate to the most probable groundwater level condition during the seismic shaking, that is the water table located at half the depth of slip surface in each soil units (see Table 2). This case represents the scenario of earthquake occurrence during the wet season. Accordingly, Fig. 6a and $\mathrm{b}$ show the pseudo-static safety factor FS and the seismic critical acceleration $k_{\mathrm{c}}$ calculated in this situation: they show unstable conditions within all the active landslides pointed out in Fig. 1a. It can be also noted that values of $\mathrm{FS}<1.2$ are reached in those parts of the urban area where the slopes are steeper, although stable up to now. Similar distribution of low values for $k_{\mathrm{c}}$ can be observed in Fig. 6b: such variable is strictly related to FS according to Eq. (1) but gives further information on seismic susceptibility at the site. Its values shall be compared with the expected maximum seismic ground acceleration at the site $a_{\mathrm{g}}$ : in this case, it is $0.196 \mathrm{~g}$ related to the 1980 Irpinia earthquake. Thus, where $k_{\mathrm{c}}$ is lower than $0.2 \mathrm{~g}$ the mass movements will take place with respect to this seismic scenario. Figure $6 \mathrm{~b}$ reveals the possible unstable areas within both the clay and sandstone units. The alluvial deposits seem to be stable, probably because of their flat slope as well as the conglomerates even though they represent a marginal portion of the territory.

Figure $7 \mathrm{a}$ and $\mathrm{b}$ show the analysis results in terms of permanent displacements, calculated by means of Eqs. (4) and (5). Correspondently to Fig. 6, the expected unstable areas, from both expressions, show the highest displacements $(>50 \mathrm{~cm})$. Differences from the two expressions used for calculating permanent displacements can be evidenced in few portions of the urban center. Both displacement maps show critical conditions also on stable areas that fall in the urban areas characterized by steep slopes. Nonetheless, when 
Table 5. Damage scale depending on permanent displacement values (after Crespellani et al., 1990).

\begin{tabular}{ll}
\hline $\begin{array}{l}\text { Permanent } \\
\text { displacement } \\
(\mathrm{cm})\end{array}$ & $\begin{array}{l}\text { Damage } \\
\text { level }\end{array}$ \\
\hline$<0.5$ & Weak \\
$0.5-5$ & Middle \\
$5-50$ & Heavy \\
$>50$ & Catastrophic \\
\hline
\end{tabular}

Table 6. Scale of damage level as a function of the values of permanent displacements (after Bray and Travasarou, 2007).

\begin{tabular}{ll}
\hline $\begin{array}{l}\text { Permanent } \\
\text { displacement } \\
(\mathrm{cm})\end{array}$ & $\begin{array}{l}\text { Damage } \\
\text { level }\end{array}$ \\
\hline$<1$ & Negligible \\
$1-15$ & Minor \\
$15-100$ & Moderate \\
$>100$ & Large \\
\hline
\end{tabular}

the seismic event is reported as PGA and magnitude value (Fig. 7a) higher permanent displacements are shown within both stable and unstable areas. Such differences are lower of one order of magnitude and can be observed within narrow portions of the territory. It can be appreciated by comparing the Lago landslide as well as the urban area limited by the dark rectangle in Fig. $7 \mathrm{a}$ and $\mathrm{b}$. According to Crespellani et al. (1990), strong damage in urban structures and infrastructures can be generated when displacements are greater than $5 \mathrm{~cm}$ (Table 5); conversely, Bray and Travasarou (2007) suggest to consider moderate damage generated by displacements ranging between 15 and $100 \mathrm{~cm}$ (Table 6). As for other classifications of damage to buildings produced by natural hazards (for instance, landslides; see at this regard Alexander, 1986, and Chiocchio et al., 1997), for a real estimation of the admissible displacements the typology of involved buildings should be taken into account, since different structures respond in very different ways to the same amount of movement (Chiocchio et al., 1997). In the specific case study at Castelfranci, under the hypothesized scenarios, where displacements higher than $50 \mathrm{~cm}$ are expected within the urban area, damage to buildings in the range between heavy and catastrophic could be produced. This is a serious warning to local administrators, and represents the main aspect to be addressed in further studies, in order to mitigate the risk related to seismically-induced slope movements in the urban center and surrounding areas.

\section{Conclusions}

Hazard maps of seismically-induced instability have been built at the Castelfranci municipality, a territory that is exposed at high seismic hazard. This territory shows instability triggered by rainfall and due to groundwater rising. These conditions suggest to use hazard maps for planning purposes and for performing works addressed to mitigate the landslide risk. In this study, considering the 1980 Irpinia earthquake as seismic scenario of reference, the following results have been provided:

a. Seismically-induced instability can be detected within active landslides both in the clay and the sandstone complexes, as well as in stable areas characterized by steep slopes;

b. Permanent displacements have been calculated by means of two empirical relationships suggested by Jibson (2007): they use different variables, respectively, $I_{\mathrm{A}}$ and PGA. Within the urban area slight differences, rarely gaining one order of magnitude, can be appreciated on the predicted permanent displacements.

The obtained results show that GIS-based hazard maps can be effectively used to detect those areas that are more exposed to likely damage by seismic shaking in order to avoid urbanization or to prevent future heavy economic losses to the society. Finally, monitoring activity is extremely useful for improving the hazard map predictions by updating static and dynamic soil behavior and conditions at the site.

Acknowledgements. We kindly acknowledge the Editor K. Tokeshi and the two anonymous referees for the valuable comments and suggestions.

Edited by: K. Tokeshi

Reviewed by: two anonymous referees

\section{References}

Alexander, D.: Landslide damage to buildings, Environ. Geol. Water S., 8(3), 147-151, 1986.

Ambraseys, N. N. and Menu, J. M.: Earthquake-induced ground displacements, Earthq. Eng. Struct. D., 16, 985-1006, 1988.

Arias, A.: A measure of earthquake intensity, in: Seismic Design for Nuclear Power Plants, edited by: Hansen, R. J., Massachusetts Institute of Technology Press, Cambridge, MA, 438-483, 1970.

Bergamaschi, F., Cultrera, G., Luzi, L., Azzara, R. M., Ameri, G., Augliera, P., Bordoni, P., Cara, F., Cogliano, R., D’Alema, E., Di Giacomo, D., Di Giulio, G., Fodarella, A., Franceschina, G., Galadini, F., Gallipoli, M. R., Gori, S., Harabaglia, P., Ladina, C., Lovati, S., Marzorati, S., Massa, M., Milana, G., Mucciarelli, M., Pacor, F., Parolai, S., Picozzi, M., Pilz, M., Pucillo, S., Puglia, R., Riccio, G., and Sobiesiak, M.: Evaluation of site effects in the Aterno River Valley (Central Italy) from aftershocks of the 2009 L'Aquila earthquake, B. Earthq. Eng., 9, 697-715, 2011. 
Boschi, E., Guidoboni, E., Ferrari, G., Mariotti, D., Valensise, G., and Gasperini, P. (Eds.): Catalogue of strong italian earthquakes from 461 b.C. to 1997, Annali di Geofisica, 43(4), 2000.

Bray, J. D. and Travasarou, T.: Simplified procedure for estimating earthquake-induced deviatoric slope displacements, J. Geotech. Geoenviron., 133(4), 381-392, 2007.

Calò, F., Calcaterra, D., Iodice, A., Parise, M., and Ramondini, M.: Assessing the activity of a large landslide in southern Italy by ground-monitoring and SAR interferometric techniques, Int. J. Remote Sens., 33(11), 3512-3530, 2012.

Chiocchio, C., Iovine, G., and Parise, M.: A proposal for surveying and classifying landslide damage to buildings in urban areas, in: Proceedings International Symposium on "Engineering geology and the environment", Athens, 1, 553-558, 1997.

Cotecchia, V. and Del Prete, M.: The reactivation of large flows in the parts of Southern Italy affected by the earthquake of November 1980, with reference to the evolutive mechanism, in: Proceedings International Symposium on Landslides, Toronto, 2, 33-38, 1984.

Crespellani, T., Ghinelli, A., Madiai, C., and Vannucchi, G.: Analisi di stabilità dei pendii naturali in condizioni sismiche, Rivista Italiana di Geotecnica, 24(2), 49-74, 1990.

Cruden, D. M. and Varnes, D. J.: Landslide types and processes, in: Landslides: Investigation and Mitigation, edited by: Turner, A. K. and Schuster, R. L., Transp. Res. Board Sp. Rep. 247, Nat. Acad. Press, WA, 36-75, 1996.

De Vita, P., Focareta, M., and Guadagno, F. M.: Il fenomeno franoso della località Chianiello nel Comune di Castelfranci (AV), Memorie Società Geologica Italiana, 56, 61-70, 2001.

Di Giulio, G., Marzorati, S., Bergamaschi, F., Bordoni, P., Cara, F., D'Alema, E., Ladina, C., Massa, M., and the L'Aquila experiment Team: Local variability of the ground shaking during the 2009 L'Aquila earthquake (April 6, 2009 Mw 6.3): the case study of Onna and Monticchio villages, B. Earthq. Eng., 9, 783-807, 2011.

DPC Working Group: Indirizzi e criteri per la microzonazione sismica. Dipartimento della Protezione Civile, MS Working Group, Rome, 2008.

Fleming, R. W. and Johnson, A. M.: Structures associated with strike-slip faults that bound landslide elements, Eng. Geol., 27, 39-114, 1989.

Hungr, O.: Flow slides and flows in granular soils, in: Proc. Int. Workshop "Occurrence and mechanisms of flow-like landslides in natural slopes and earthfills", edited by: Picarelli, L., 37-44, 2003.

Hungr, O., Evans, S. G., Bovis, M., and Hutchinson, J. N.: Review of the classification of landslides of the flow type, Environ. Eng. Geosci., 7, 221-238, 2001.

IAEG Commission on Landslides: Suggested nomenclature for landslides, Bull. Int. Ass. Eng. Geology, 41, 13-16, 1990.

Infrastructure Ministry: Decreto 14/01/2008, Norme Tecniche per le Costruzioni, G.U. no. 29, 04/02/2008.

Jibson, R. W.: Predicting earthquake-induced landslide displacements using Newmark's sliding block analysis, Transp. Res. Record, 1411, 9-17, 1993.

Jibson, R. W.: Regression models for estimating co-seismic landslide displacement, Eng. Geol., 91, 209-218, 2007.
Jibson, R. W., Harp, E. L., and Michael, J. M.: A method for producing digital probabilistic seismic landslide hazard maps: an example from the Los Angeles, California area, US Geological Survey Open-File Report 98-113, 1998.

Jibson, R. W., Harp, E. L., and Michael, J. M.: A method for producing digital probabilistic seismic landslide hazard maps, Eng. Geol., 58, 271-289, 2000.

Locati, M., Camassi, R., and Stucchi, M. (Eds.): DBMI11, the 2011 version of the Italian Macroseismic Database, Milano, Bologna, doi:10.6092/INGV.IT-DBMI11, 2011.

Menardi Noguera, A. and Rea, G.: Deep structure of the Campanian-Lucanian Arc (Southern Apennine, Italy), Tectonophysics, 324, 239-265, 2000.

MPS Working Group: Redazione della mappa di pericolosità sismica prevista dall'Ordinanza PCM del 20 marzo 2003, Final report for the Department of the Civil Protection, INGV, 65 pp., 2004.

Newmark, N. M.: Effects of earthquakes on dams and embankments, Geotechnique, 15(2), 139-160, 1965.

Parise, M.: Observation of surface features on an active landslide, and implications for understanding its history of movement, Nat. Hazards Earth Syst. Sci., 3, 569-580, doi:10.5194/nhess-3-5692003, 2003.

Parise, M. and Wasowski, J.: Landslide activity maps for the evaluation of landslide hazard: three case studies from Southern Italy, Nat. Hazards, 20(2/3), 159-183, 1999.

Parise, M., Coe, J. A., Savage, W. Z., and Varnes, D. J.: The Slumgullion landslide (southwestern Colorado, USA): investigation and monitoring, in: Proc. Int. Workshop "Occurrence and mechanisms of flow-like landslides in natural slopes and earthfills", edited by: Picarelli, L., 253-263, 2003.

Parise, M., Federico, A., and Palladino, G.: Historical evolution of multi-source mudslides, in: Landslides and Engineered Slopes. Protecting Society through Improved Understanding, edited by: Eberhardt, E., Froese, C., Turner, A. K., and Lerouil, S., Proceedings 11th Int. Symp. Landslides, Banff (Canada), 3-8 June 2012, 1, 401-407, 2012.

Patacca, E. and Scandone, P.: Geology of the Southern Apennines, Boll. Soc. Geol. It., Special Issue 7, 75-119, 2007.

Patacca, E., Sartori, R., and Scandone, P.: Tyrrhenian basin and Apenninic areas: kinematic relations since Late Tortonian times, Memorie Società Geologica Italiana, 45, 425-451, 1990.

Pellegrino, A., Picarelli, L., and Urciuoli, G.: Experiences of mudslides in Italy, in: Proc. Int. Workshop "Occurrence and mechanisms of flow-like landslides in natural slopes and earthfills", edited by: Picarelli, L., 191-206, 2003.

Peluso, G.: Carta geologica e della franosità del comune di Castelfranci, Archive of the Castelfranci Municipality, 1999.

Rainone, M. L., Vessia, G., Signanini, P., and Di Benedetto, S.: Evaluating site effects in near field conditions for microzonation purposes: the case study of the 2009 L'Aquila earthquake, Italian Geotechnical Journal, in press, 2013.

Sibson, R.: A brief description of natural neighbor interpolation, in: Interpreting Multivariate Data, edited by: Barnett, V., Chichester, John Wiley, 21-36, 1981.

Tarquini, S., Isola, I., Favalli, M., Mazzarini, F., Bisson, M., Pareschi, M. T., and Boschi, E.: TINITALY/01: a new Triangular Irregular Network of Italy, Ann. Geophys.-Italy, 50(3), 407-425, 2007. 
Valensise, G. and Pantosti, D.: Database of potential sources for earthquakes larger than M 5.5 in Italy, Ann. Geophys.-Italy, suppl. 44(4), 797-964, 2001.

Westaway, R. and Jackson, J.: The earthquake of 1980 November 23 in Campania-Basilicata (Southern Italy), Geophys. J. R. Astron. Soc., 90, 375-443, 1987.

WP/WLI (Working Party on World Landslide Inventory): A suggested method for describing the activity of a landslide, Bull. Int. Ass. Eng. Geology, 47, 53-57, 1993. 